\title{
Delineation of post-industrial landscapes of the Upper Silesian corridor in the Basin of Ostrava
}

\author{
Jaromír Kolejka1, Martin Klimánek², Stanislav Martinát ${ }^{3}$, Aleš Ruda4 \\ 1'Institute of Geonics, Academy of Sciences of Czech Republic, Ostrava, Brno branch, Drobného Str. 28, 60200 Brno, Czech Republic \\ E-mail address (corresponding author): kolejka@geonika.cz \\ 2Department of Geoinformation Technologies, Faculty of Forestry and Wood Technology, Mendel University, Zemědělská Str. 3, \\ 61300 Brno, Czech Republic \\ 3Institute of Geonics, Academy of Sciences of Czech Republic, Ostrava, Studentská Str. 1768, 70800 Ostrava, Czech Republic \\ ${ }^{4}$ Department of Regional Development and Public Administration, Faculty of Regional Development and International Studies, \\ Mendel University, tř. Gen. Píky Str. 7, 61300 Brno, Czech Republic
}

\begin{abstract}
The post-industrial landscapes represent a legacy of the industrial revolution. There have been gradually formed numerous enterprises of various industry branches on the territory between Czech-Polish border in the North and Moravian-Silesian Beskydes Mts. (a part of Carpathians) in the South (the western border follows the foothills of Hercynian Bohemian Highlands). In the given study, there are demonstrated examples of the post-industrial landscape in the concerned area of Ostrava, which is a part of the so called Upper Silesian industrial corridor that is intensively linking industrialized region of Upper Silesia in Poland and the Czech Republic with other developed regions of Europe to southwest through the Moravian Gate to the Danube region. This paper demonstrates the procedure for defining the post-industrial landscapes in general, their classification and standardization using the available data sources and GIS technology. For the processing the data of the deployment of brownfields, contaminated sites, industrial constructions of architectural heritage, mining points and areas, human made landforms, industrial and landfill sites etc. were used. They document the genesis, the territorial shape and the geographic position of the post-industrial landscape in the study region. In the concerned area of Ostrava four "rural" post-industrial landscapes were identified and classified into three different genetic types. This paper also presents a methodology for identifying, mapping and classification of post-industrial landscapes on the basis of publicly available and state-managed databases.
\end{abstract}

KEY WORDS: delineation, brownfields, Upper Silesia, GIS

\section{Introduction}

The current cultural landscape between the Moravian Gate and Czech-Polish border in the northeast of the Czech Republic (Fig. 1) has emerged since the prehistoric times from the original relatively balanced forest and pasture land with a small field management area rich in atmospheric rainfalls. The radical impulse to the development of the current state was given by the Industrial Revolution at the beginning of the $19^{\text {th }}$ century. In the glacial waved Ostrava Basin on the border of the historic region of Moravia and Silesia, there appeared strongly changed the landscape because of the dominant effect of industrial activities connected to the coal mining and iron smelting.

The research in the Czech Republic showed post-industrial landscapes (then PIL) of various types using generally available data from public or state-managed geodatabases (KOLEJKA ET AL., 2012). It is assumed that the analogical data (RULKENS \& HONDERS, 1996; FERGUSON, 1999) are available in other European Union countries and the world. It is thus possible to apply a similar methodology to such data in other countries and make the results comparable. 


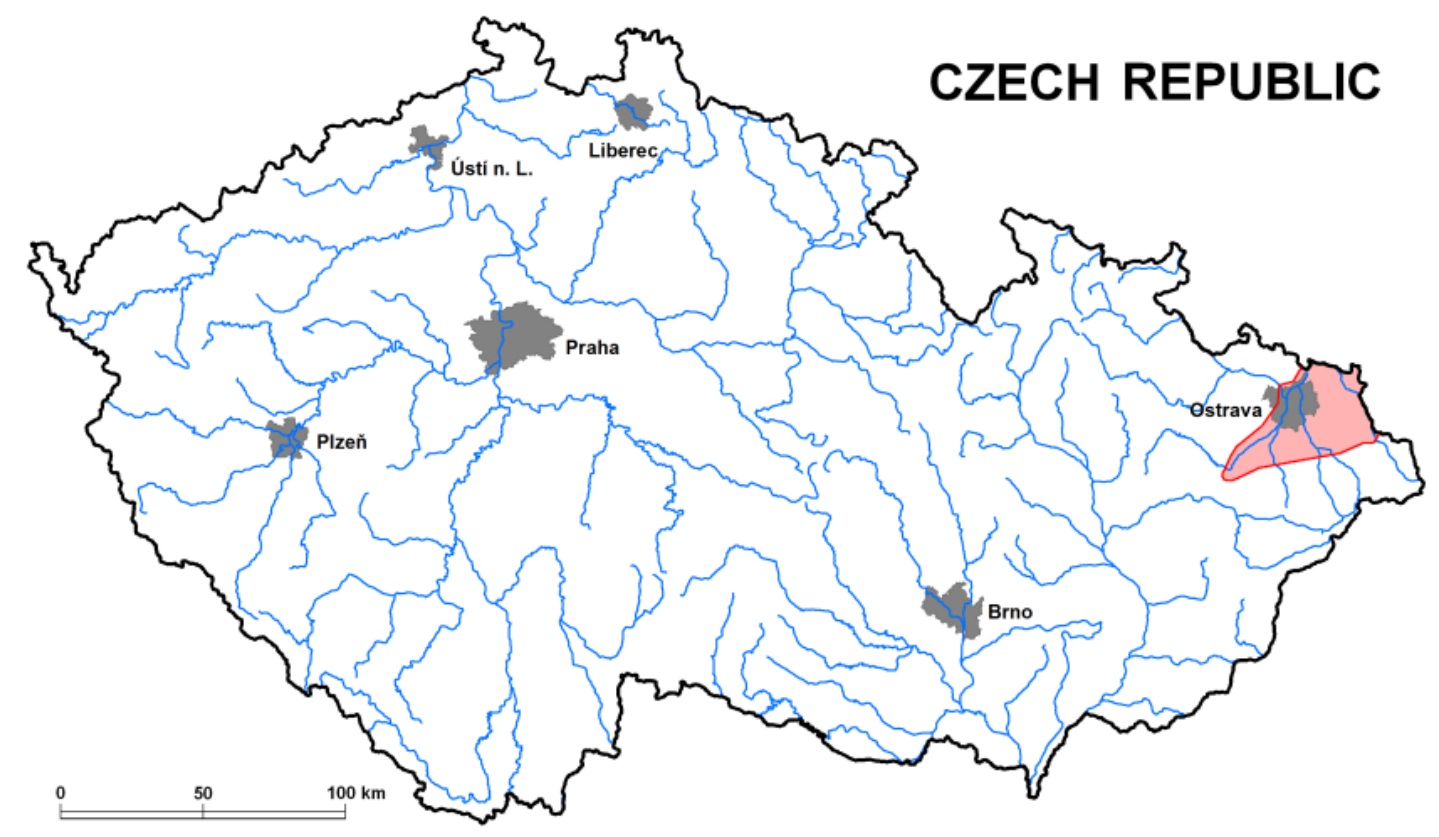

Fig. 1. Location of the concerned area in the Czech Republic

\section{The current state of the art}

The functional industrial landscape has long been the focus of attention of the scientific community. Interest in the post-industrial landscape has grown only during the last two decades. The post-industrial landscape is a territory whose structural, functional and physiognomic characteristics were directly and indirectly shaped by the previous industrial activities and life of the industrial society, and these activities led to the typical changes in the natural, economic, human and spiritual structure, in which they are described and do not have the original purposes. The post-industrial landscape thus represents a geographic concentration of these changes, as the identification evidence, and covers a sufficiently large area on the earth's surface (KOLEJKA ET AL., 2012).

The post-industrial landscape, but more often rather objects of the industrial heritage are of interest to both the general public and professional circles. Especially the architectural value of buildings and the whole industrial areas are respected. Given that, a lot of industrial buildings ceased to perform its original function, they were often threatened by a demolition or such modifications that would remove their character and notability. In a lot of countries since the 1970s, there have taken place diverse forms of revitalization of industrial buildings and sites, usually they're converted into shopping, recreational and residential areas. However, there still remains a tremendous amount of endangered buildings and sites of the industrial heritage.

The existence of the post-industrial landscape is generally accepted as a reality of the contemporary world. Its scientific research, however, is lagging behind the needs. Probably the primary research initiative was conducted by architects studying objects of the industrial heritage. Some research companies were established within academic institutions (Research Centre for Industrial Heritage of the Czech Technical University in Prague) or at the national level (e.g. Association for Industrial Archaeology in England, Canadian Industrial Heritage Centre) or even at the international level (The International Committee for the Conservation of the Industrial Heritage). The latter mentioned institution (TICCIH) in 2003 even published the so-called Nizhny Tagil Charter for the Industrial Heritage, which highlights the crucial importance of the industrial heritage of human culture, whether it is a city centre or an open landscape (LOURES, 2008). Wider relationships of the cultural heritage buildings and landscapes are being studied less, although the interest in this issue is hopefully growing. In comparison to a noticeable interest of the industrial architecture, yet the significantly less attention is paid to the environment, in which are these objects placed, therefore, the landscape. It should be noted that the practical application of knowledge from the research of the landscape is reflected especially in urban landscapes of cities of Western and Central Europe and North America, i.e. in the "urban post-industrial landscape". The broader "rural" industrial space is usually characterized by areas affected by underground or surface mining of coal (Ruhr, Lorraine, Lower Lusatia, Upper Silesia, under the Ore Mountains) and following enterprises of the energy and metallurgical industries. One part of 
these "urban" and "rural" industrial landscapes underwent a spontaneous transformation into the post-industrial landscape by a simple deindustrialization, i.e. by ceasing the industrial production, leaving the original industrial sites or their transformation for other purposes. On rare occasions by organized endeavouring of state, NGO and private entities, there took place an extensive aimed transformation of an area into a modern purpose-built post-industrial landscape. Among the examples, there are some larger areas such as the Ruhr (Emscher-Park, FRAGNER, 2005), Wales (around Blaenavon, RoGERS, 2006) or England (Dearne Valley in South Yorkshire - LING AT AL., 2007). In the centre of attention of the professional community engaged in the post-industrial landscape, there traditionally dominate architectural (CASHEN, 2006), economy (SHAHID \& NABESHIMA, 2005; DUNHAM-JONES, 2007), social (KIRKWOOD, 2001; KIRK, 2003; HANSEN \& WINTHER, 2006) and biological, respectively ecological aspects, particularly with regard to the occurrence of biotic communities and species, soil remediation and water (KIRKWOOD, 2001, KEIL, 2005). Initial contributions and monographs even on the topic of the postindustrial landscape were published (see KIRKWOOD, 2001, KIRK, 2003, KeIL, 2005, KOLEJKA, ET AL., 2012; etc.). In the contemporary Czech literature there are quite a few posts concerned with the post-industrial landscape (FRAGNER, 2005; KOLEJKA, 2006; VRÁBLÍKOVÁ \& VRÁBLÍK, 2007; KOLEJKA ET AL., 2011; KLUSÁČEK ET AL., 2011; KoLEJKA \& KLIMÁNEK, 2012), although their number has been increasing in recent years.

The landscape formed by industry is by ANTROP (2005) classified among the landscapes of revolution periods. This landscape was quickly created and it also quickly disappears as a result of technological and social change, and war conflicts. Industrial landscape as a landscape with significant to dominant influence on the landscape character, structure and functioning, is usually investigated in close connection to the urban landscape. Not always, however, the industrial landscape is necessarily urban. Industrial buildings, areas and related infrastructure are often outside the residential centre (HAYES, 2006), yet they are dominant in the given area. The industrial landscape is often identified with a landscape affected by large-scale surface mining of raw materials, especially energetic - coal, oil, peat, or building gravel, sand, stone, or ores of some metals (Germany - HÜTTL, 1998; Czech - SKLENiCKA \& ChARVATOVA, 2003; VRÁBLÍKOVÁ \& VRÁBLíK, 2007; Spain - CONESA ET AL., 2008, Poland - DULIAS, 2009). Geographical demarcation (boundaries and content) of post- industrial remained very vague and indeterminate until recently (see LOURES, 2008).In the case of Slovenia (HLADNIK, 2005), the industrial landscape is as a special type defined according to the share of industrial lands (registered in the CORINE LC project) of the total area of a cadastral territory. According to LINGA ET AL., (2007), the post-industrial landscape can be considered an area (for example Dearne Valley) that is significantly affected by mining of raw materials, with numerous abandoned buildings, brownfields, but also those influenced by the regeneration programs and requiring different than conventional approach when deciding about its future. STUCZYNSKI ET AL. (2009) relied during the geographical definition of post-industrial regions in the European Union on the database CORINE LC 2000, registering industrial, mining and landfill sites, without distinguishing between functional areas of these categories from nonfunctional. KOLEJKA ET AL. (2011) and KOLEJKA \& KLIMÁNEK (2012) have developed and used a methodology that allows GIS technology supported mapping and classification of post-industrial landscapes at regional and national level using publicly available geodatabases of cultural heritage objects, brownfields, chemical loads, anthropogenic landforms, industrial and mining sites, etc. At the detailed local level of mapping, based entirely on different bases, with the exception of one rare attempt (KoLEJKA, 2010), methods for the diagnosis of post-industrial landscape and its classification have not been developed.

\section{Defining characteristics of the post-industrial landscape}

The post-industrial landscape is a legacy of the industrial era of the human society development. By the industrial society initially created, or at least influenced and now abandoned landscape is characterized by a number of specific physiognomic, structural and functional attributes, which represent the last remnants of the industrial period. While in the functioning industrial landscape these parameters are "recent", in the post-industrial landscape they are characterized as "fossil". We talk about characteristics related to any current landscape structures.

(1) In the natural (primary) structure: caused by the change of topoclimate (originally actively created heat island - now inertial maintaining above the former objects in weakened form, atmospheric substances - gas and dust, usually from poorly maintained surfaces and objects), changes in runoff (artificial surfaces, drainage area, artificial water bodies), removing or covering of soil (by own objects 
and fills in their area), changes in terrain (mining, industry, water management, military, transport and other forms of relief), changes in the contact with the geological environment (removal of the weathered objects when setting foundations, insulation and buffer fills, soil and rubbish dumps, industrial waste, areas of surface and underground mining), a radical change of biota (in the extreme case a total removal of natural or cultural vegetation and the creation of artificial surfaces with the onset of ruder and segmental species, a complete change of fauna dominated by synatrop or invasive species, but with the return of elements of the original flora and fauna).

(2) In the economic (secondary) structure: the land use is characterized by the dominant abandoned or disintegrated manufacturing area with typical objects (buildings, chimneys, boilers, storage), large abandoned or poorly used communication areas and equipment (handling areas, dock, station, bundles of pipe, belt conveyors, parking areas, now an inefficient dense network of roads and railways, freight lifts, etc. ), passive mining areas (quarries, dumps, temporary storage), abandoned or poor water management facilities (dams, sampling devices, pumping and pressure stations, swimming pools, ponds, canals), abandoned and neglected original residential and service buildings (workers' colonies, residential areas, large blocks of buildings - according to a period of construction) struggling with social problems. This category also includes abandoned objects of agricultural animal production, military objects and areas and transport logistics, etc.

(3) In the human (social, tertiary) structure: because of the changes of interest there are devastated areas, abandoned areas without maintenance, decline and loss of original functionality of cultural, educational, healthcare, catering, sports, leisure, entertainment and other buildings, facilities associated with the former industry and industrial society. The opposite case is an contrary an introduction of different degrees of protection over certain objects. Social conditions have changed for many residents. In some cases, change of social status led to the emigration, in others to the immigration.

(4) In the spiritual structure: the perception of the landscape has changed by locals and also visitors. In part, this change is also related to the change of political conditions, both economic and social, and openness in knowledge concerned with environmental conditions, but also with different accessibility to power and the power authorities. Objects that have been a source of income and the path to higher living standards, and therefore perceived positively, can be seen at once (after the loss of original functionality and against the former employee and his/her family) negatively. In some places, you cannot deny the formation of strong genius loci, whether positive or negative.

\section{Used data}

From the review of evidence of the postindustrial landscape, it is clear that theoretically you can find plenty of characters that show the existence of this type of land in respect of their territorial concentration. The situation in the field of the real data is different as was expected. In the Czech Republic, there has been created a number of geodatabases in the past, which uniformly record information about some of the PIL indicators, but usually it is necessary to interpret them in an appropriate way. Only partially, it is possible to cover the spectrum of the symptoms listed above by available quality data. Yet, these data are generally available, if necessary, to repeat the procedure for comparative purposes in other areas and, where appropriate, in the same area at different times. The following overview of the geodatabase (Tab. 1) is sufficient to satisfy the identification and mapping of PIL, although it does not cover completely all the required topics.

\section{Methods of processing}

The actual procedure of defining PIL on the basis of available relevant data can be divided into a sequence of steps:

Step 1: Collection of data (based on the prior knowledge of the available geodatabases, managing data, by their direct use or interpretation may be indicators PIL determined). In any case, an internet search using one of the best search engines can be used, leading to find appropriate mapping sites. Any user data were loaded into the ArcGIS v. 9.2 and united in the coordinate system S-42.

Step 2: Specialized interpretation of the content geodatabases. During which are the basic data of used available geodatabases evaluated from the point of indicating a possible role of included elements for PIL characteristic (see Tab. 1) and shown for clarity in a map (Fig. 2). It is obvious that the indicators of postindustrial landscape create spatial clusters. It remains a question, what will be the maximum distance of the individual indicators that were still in one post-industrial landscape within a specific concentration of indices representing PIL. 
Table 1. Data sources used for identifying, mapping and classification of post-industrial landscapes in the Czech Republic

\begin{tabular}{|c|c|c|c|c|}
\hline No & Data resource name & Resource manager & $\begin{array}{c}\text { Chosen characteristics of the } \\
\text { dataset }\end{array}$ & $\begin{array}{l}\text { Interpretation of the } \\
\text { relationship to the industrial } \\
\text { heritage }\end{array}$ \\
\hline 1 & $\begin{array}{l}\text { ZABAGED - the } \\
\text { basic package of } \\
\text { geographic data }\end{array}$ & $\begin{array}{l}\text { Czech Office for } \\
\text { Surveying, Mapping } \\
\text { and Cadastre }\end{array}$ & $\begin{array}{l}\text { 1:10000 } \\
\text { polygons } \\
\text { S-JTSK }\end{array}$ & $\begin{array}{l}\text { mining areas, industrial areas, } \\
\text { waste dumps, heaps }\end{array}$ \\
\hline 2 & $\begin{array}{l}\text { CORINE Land Cover } \\
2006\end{array}$ & $\begin{array}{l}\text { Ministry of the } \\
\text { Environment }\end{array}$ & $\begin{array}{l}\text { 1:50 } 000 \\
\text { polygons } \\
\text { WGS84, min. area } 25 \text { ha }\end{array}$ & $\begin{array}{l}\text { industrial areas - category } \\
121 \text {, mining areas - category } \\
131 \text {, dumps - category } 132\end{array}$ \\
\hline 3 & $\begin{array}{l}\text { The system of } \\
\text { registration of } \\
\text { contaminated sites }\end{array}$ & $\begin{array}{l}\text { CENIA- state } \\
\text { organization }\end{array}$ & $\begin{array}{l}\text { location according to coordinates } \\
\text { obtained in the field with the help } \\
\text { of technology GPS, points S-JTSK }\end{array}$ & chemical loads \\
\hline 4 & $\begin{array}{l}\text { National Database of } \\
\text { Brownfields }\end{array}$ & $\begin{array}{l}\text { Czechinvest - state } \\
\text { organization }\end{array}$ & $\begin{array}{l}\text { about } 1: 10000 \\
\text { points } \\
\text { S-42 }\end{array}$ & $\begin{array}{l}\text { brownfields according to the } \\
\text { original application, catalog of } \\
\text { sites with localization by } \\
\text { municipalities or addresses }\end{array}$ \\
\hline 5 & Undermined areas & $\begin{array}{l}\text { Czech Geological } \\
\text { Survey }\end{array}$ & $\begin{array}{l}\text { about 1:50 } 000 \text { polygons and points } \\
\text { S-JTSK (min. } 4 \mathrm{~km}^{2} \text { area as an area } \\
\text { smaller as the point) }\end{array}$ & undermined areas and points \\
\hline 6 & $\begin{array}{l}\text { Objects of the } \\
\text { industrial heritage }\end{array}$ & $\begin{array}{l}\text { Research Centre for } \\
\text { Industrial Heritage } \\
\text { FA ČVUT in Prague }\end{array}$ & $\begin{array}{l}\text { GPS location of the centers of } \\
\text { gravity of objects of interest in } \\
\text { Excel table }\end{array}$ & $\begin{array}{l}\text { preserved objects of the } \\
\text { industrial architecture }\end{array}$ \\
\hline 7 & $\begin{array}{l}\text { Urbanized areas of } \\
\text { cities over } 50,000 \\
\text { inhabitants }\end{array}$ & $\begin{array}{l}\text { CENIA, GEODIS } \\
\text { BRNO }\end{array}$ & $\begin{array}{l}\text { innovative set of maps Arc ČR } 500 \\
\text { v. } 2.0,2003 \text {, own visual interpretation } \\
\text { of published aerial photographs, } \\
\text { built-up areas of residential, } \\
\text { community and service character }\end{array}$ & $\begin{array}{l}\text { represent a mix of objects of } \\
\text { industrial and post-industrial } \\
\text { landscape incorporated into } \\
\text { the dominant urban city } \\
\text { landscape }\end{array}$ \\
\hline 8 & District towns & $\begin{array}{l}\text { Czech Statistical } \\
\text { Office }\end{array}$ & $\begin{array}{l}\text { cadastral territory belonging to } \\
\text { district towns }\end{array}$ & $\begin{array}{l}\text { enable to separate the urban } \\
\text { landscape of district towns } \\
\text { from the rest of the territory }\end{array}$ \\
\hline
\end{tabular}

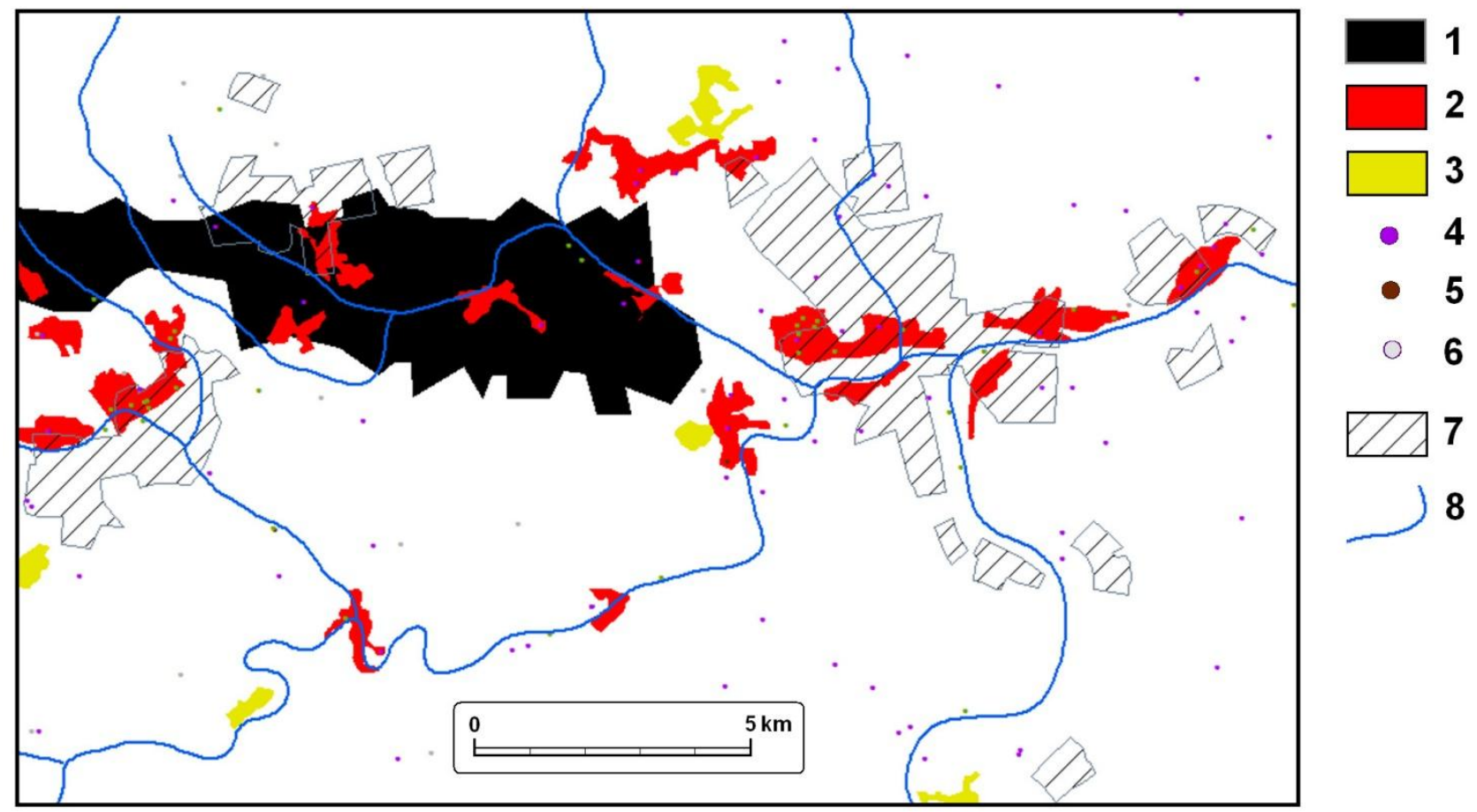

Fig. 2. Comprehensive cartographic representation of the relevant data from available databases appropriate to indicate the post-industrial landscape

1- mining and undermined areas; 2 - industrial areas with brownfields; 3 - dumps; 4 - contaminated sites; 5 - brownfields; 6 - small undermined locations; 7 - urbanized areas; 8 - water flows (Data sources: CENIA, Czech Geological Survey, CORINE LC 2006, CzechInvest, ČÚZaK, ARCDATA PRAGUE) 
Step 3: Creation of the polygon layer from the point layer of old chemical loads, brownfields and small undermined locations. Conversion from the point to polygon layer is necessary to obtain the area output and to minimize the incoherent subjective evaluation of the points concentration indicating the location of the old chemical loads. GIS tools allow you to "wrap" a point or polygon from any page by variously wide belt (buffer) according to the purpose of work. Questionable may be determination of the size of the buffer. By experimenting with several suggestions, there was finally reached determination of buffer width $(500 \mathrm{~m})$. Its practical advantage is that the circle formed around a central point has a diameter of $1 \mathrm{~km}$. Between two adjacent old loads, which can form a common polygon, is once again up to $1 \mathrm{~km}$ (wrapping buffers are touching at the same point in an extreme case). A distance of around $500 \mathrm{~m}$ from the source of the pollutant can also be very conventionally considered a reach of this source, although factors of soil, geological and hydrogeological environment can certainly deform the reach of pollution sources strongly (Fig. 3). However, it is not possible to examine and determine the shapes and sizes of wrapping zones around more than 8000 used "points" areas of old loads during data processing. The inspiration for the final decision on the width of the buffer was also foreign experience (HLADNIK, 2005). In fact, the range of influence of each indicator is different and in its shape also reflected the character of the environment. Opinions on this issue probably vary among experts of different professions. Points (and similar areas) will in any case represent the cores of the potential post-industrial areas.

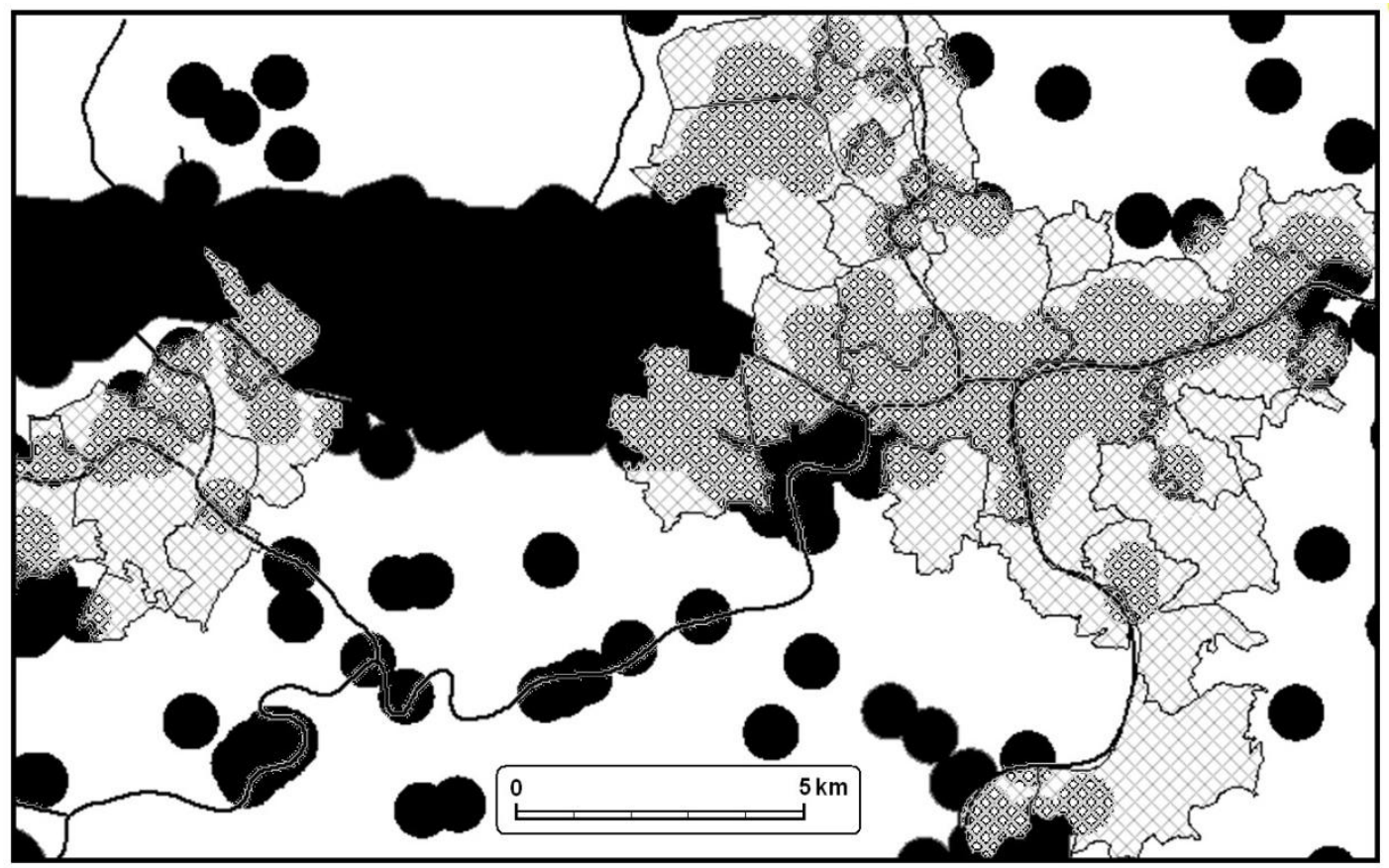

Fig. 3. Example of "wrapping" of point locations and areas of indicators PIL buffers of the width of $500 \mathrm{~m}$ (black) by overlapping and then removing areas of indicators of post-industrial landscape in areas of large cities (grey) (Data sources: CENIA, Czech Geological Survey, CORINE LC 2006 CzechInvest, ČÚZaK, CSO)

Step 4: Creation of analogous buffer zones along the outer edges of areas - polygons of large (over $4 \mathrm{~km}^{2}$ ) undermined areas (Fig. 3), heaps, dumps or industrial areas with brownfields. Other industrial areas without brownfields, respectively in contact with them, have been excluded from processing. In the case of industrial and commercial areas (from the CORINE LC database), it was necessary to make qualified choice. Into the further processing, there have been included only those areas, inside or outside of which a distance of $100 \mathrm{~m}$ (maximum position error of the normal tourist GPS) there was at least one brownfield. These selected areas of 121 categories were then similarly supplied with the analogous buffer of the width of $500 \mathrm{~m}$. The buffer width $500 \mathrm{~m}$ symbolizes similar direct or visual range of these objects. In this way, there is a significant overestimation of the area especially of smaller objects, but we must consider that the impact of these objects in their surroundings does not end with their edge. The width of the buffer is a certain compromise between the knowledge and the real scope of the impact of all types of buildings of all sizes, in essence, absolute lack of data on the specific situation around them. 
Step 5: Integration of polygon layers of buffers around sites of old burdens and brow fields with areas of other object types (polygons) provided on the outer side buffers of equal width. This step can combine the previous five variables and (in certain cases) associate them into heterogeneous complexes (if possible). By areal pouring of buffers around the points and polygons provided buffers may thus arise polygons consisting of at least two buffer areas (arbitrarily out of 5 types of pointers or areal locations individually or of their various combinations, but involving maximum of all five types of areas with at least one representative of each type, except the areas provided the buffer without the contact with other locations). A wide size range of areas arises naturally in this step (Fig. 3). Areal minimum is a single isolated buffer area around a point object (about $0.8 \mathrm{~km}^{2}$ ). The upper size limit is not determinable in advance.

Step 6: Filtering out the urbanized areas of big cities with populations over 50,000 and land of district towns of all sizes. Cities of over 50,000 inhabitants include a large number of industrial heritage objects, but the character of the area is shaped by current activities, whether it is a living, modern and traditional manufacturing, services, cultural, business and sports activities, and objects connected with all of them. Although the significant concentrations of abandoned buildings and sites may occur, compared with the "active" areas, the "fossil" areas are less important and usually do not shape post-industrial landscapes. Similar is the case with the district towns characterized by concentrations of recent residential, commercial and manufacturing activities. In relation to them, the area's industrial heritage is featureless. Identification of "urban" postindustrial landscape is although possible at a higher resolution at the local, resp. lower choric level. In this case, however, it is the definition of "rural" post-industrial landscape at the national level outside (large) urban areas, where industrial heritage plays an important physiognomic role (Fig. 3). Outside the big cities there is no reason to doubt the versatile effects of post-industrial areas in the countryside, in many cases (in areas of concentration of objects of interest the effect upon the physiognomic and environmental may be even dominant).

Step 7: Elimination of small areas representing the mere potential core units of post-industrial landscape. The result of processing of geographic data indicating post-industrial areas is a set of areas of different shapes and sizes. However, the area of a certain size can be considered as the post-industrial landscape. Determination of the minimum size is again a subjective task. This task may rely on a number of factors:

(1) At the national level in the Czech Republic with the coarsest level of resolution of the materials (undermined area) it is possible to theoretically distinguish the area around the minimum of $4 \mathrm{~km}^{2}$. However, the isolated buffer area around the point is about $0.8 \mathrm{~km}^{2}$, i.e. 80 ha. Integrated landscape mapping at a scale of 1:500 000 has a minimum area distinguished by an area of $5 \times 5 \mathrm{~mm}$, i.e. $2.5 \times 2.5 \mathrm{~km}$, which is $4.25 \mathrm{~km}^{2}$. When rounded up to whole numbers, it is possible to come to a conventional setting of a minimum area of an individual unit of post-industrial landscape in the range of $5 \mathrm{~km}^{2}$, the minimum distinguished area must necessarily exceed the minimum "areal" undermined territory, originally $4 \mathrm{~km}^{2}$, but provided a buffer that is a total of $5 \mathrm{~km}^{2}$.

(2) The most common size of the cadastral territory of the Czech Republic (outside the borderlands and cities ) is $4-6 \mathrm{~km}^{2}$, this area is normally taken as the basic planning unit for territorial and landscape planning (e.g. for the creation of master plans USES = territorial system of ecological stability).

(3) An estimated $5 \mathrm{~km}^{2}$ is the normal size of a small town, $\mathrm{w}$ here post-industrial areas can already play a dominant role in the appearance (perception) and planning tasks.

(4) In geomorphologically broken area, such as the Czech Republic, the landscape is changing at the latest after about 1 hour of walking, which may mean approximately $5 \mathrm{~km}$ long route, in broad valleys it can be an area of around 4-6 $\mathrm{km}^{2}$.

(5) A medium distance between country settlements is changing from $3 \mathrm{~km}$ in an old settlement area in Bohemia to $7 \mathrm{~km}$ in Moravia, but even here there is a common distance of villages $5 \mathrm{~km}$ and more, if we take into account the mountainous regions of the country.

Based on the above, a conventional setting of a minimum area of individual units of post-industrial landscape in the range of $5 \mathrm{~km}^{2}$ is reached. Thus, areas smaller than $5 \mathrm{~km}^{2}$ can be considered the cores of the post-industrial landscape, while areas larger and equal to this limit value can be classified the territories of the post-industrial landscape (Fig. 4). So the smaller areas under $5 \mathrm{~km}^{2}$ can be excluded from the process of the classification and typing. 


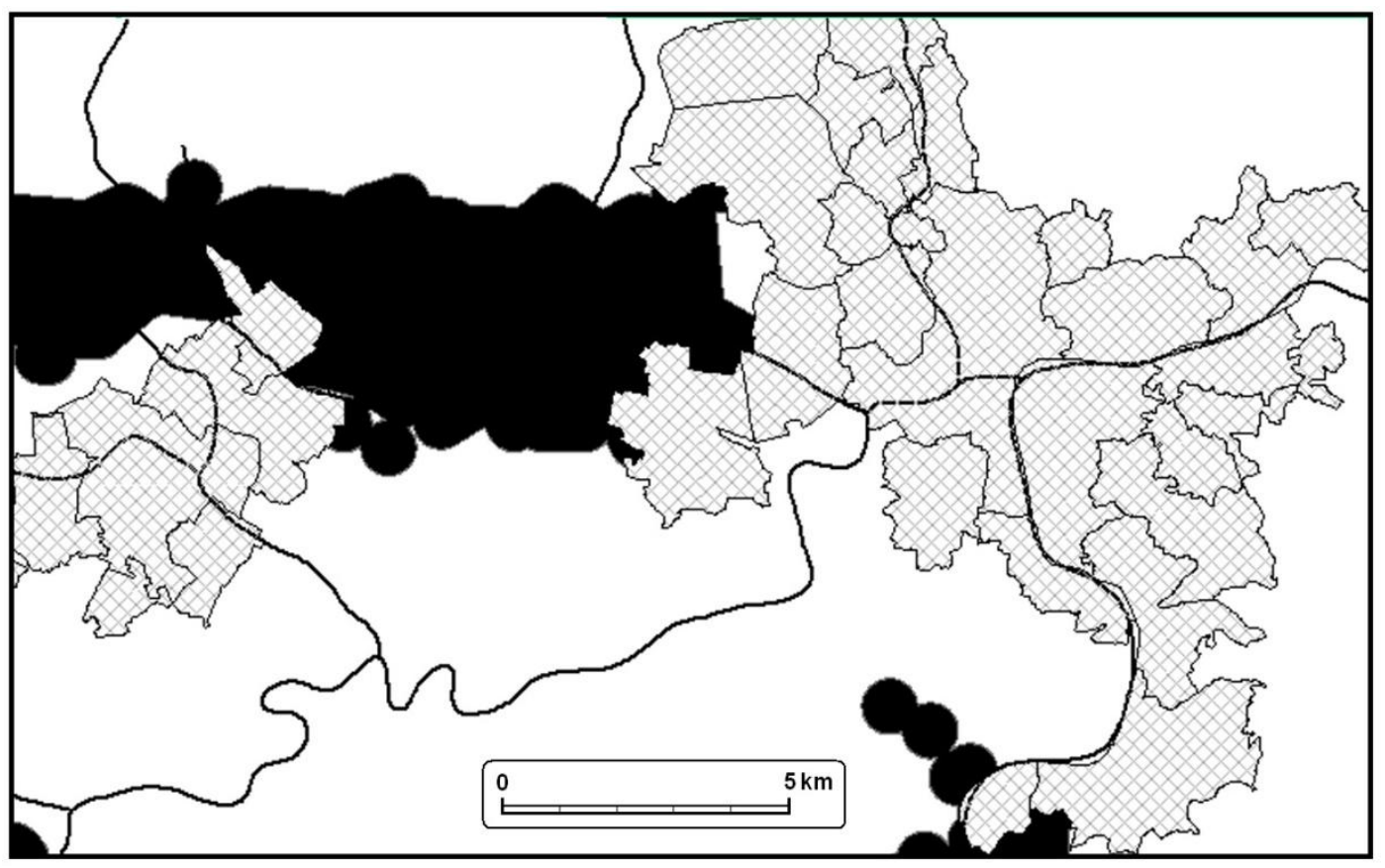

Fig. 4. Removal of areas of indicators of post-industrial landscape in big cities areas and connected areas of indicators smaller than 5 km² (Data sources: CENIA, Czech Geological Survey, CORINE LC 2006, Czechinvest, ČÚZaK, ČSÚ)

Step 8: Rounding contours of the detected postindustrial landscapes. The areas identified in the previous steps in many cases represent very bizarre formations with very jagged edges in ground plans (Fig. 4) depending on which individual areas determined by buffers are composed and poured together. This trait can be attributed to the used procedure and GIS technology/tools. Unusual contours are formed mainly in the places with the lack of overlap - only contact - of circular buffers around point objects. For entirely practical reasons, it was necessary to smooth the outlines with a method of cartographic generalization that preserves the overall shape of the object and minimizes the surface area changes. By an appropriate tool in ArcGIS software it is possible to generalize contours in their course, without a fundamental change in the overall contour of the area and its surface. For these purposes Simplify Polygon tool is used (in Toolbox: Cartography Tools - Generalization in software ArcGIS 9.2), working with several generalizing algorithms. Experimentation has shown that good results are obtained while using the Bend Simplify algorithm that preserves the shape of the object and reduces the local extreme protrusions of the contour line. Smoothing the line has been set by selecting the so called Reference Baseline piecewise of $1000 \mathrm{~m}$. The result is the creation of acceptable contours of individual post-industrial landscapes (Fig. 5), which is especially useful for the further use of the results, particularly in the decision-making sphere. The sizes of the areas inside the new (generalized) contours remained virtually untouched. The resulting simplification of contours is especially useful for administrative and planning tasks, as the "smooth" course of boundaries of the individual post-industrial landscapes is known.

Step 9: Classification of units of the postindustrial landscape. A classification criterion of the defined areas of post-industrial landscape is their genesis that is the way how this type of landscape was created. In essence, it is the assignment of the current post-industrial landscape to that (those) activity (activities) which was (were) decisive during its formation. Genetic factors are, of course, the previous dominant activities, whether individual industries, military, housing or agriculture, mining, or land filling of waste, etc. Controlled classification of detected cases of postindustrial landscapes meant the insertion of the concrete case into the pre-specified type, generally identified by one-to-four word titles.

The criterion for the selection of words and their number was the areal representation of areal indicators of the post-industrial landscape (border percentage \%: $75,50,25,10$ ), or the percentage of point indicators to the total number of indicators of the post-industrial landscape (the same border percentage) and the combination of representation areal and point indicators (Fig. 6). In any case, the identification of the type of defined post-industrial landscape is done one-to-four word titles with the declining definitional meaning of the word 
when reading from left to right, such as mining post-industrial landscape, mining textile postindustrial landscape, textile engineering glass post-industrial landscape, glass chemical military engineering post-industrial landscape (Fig. 7).

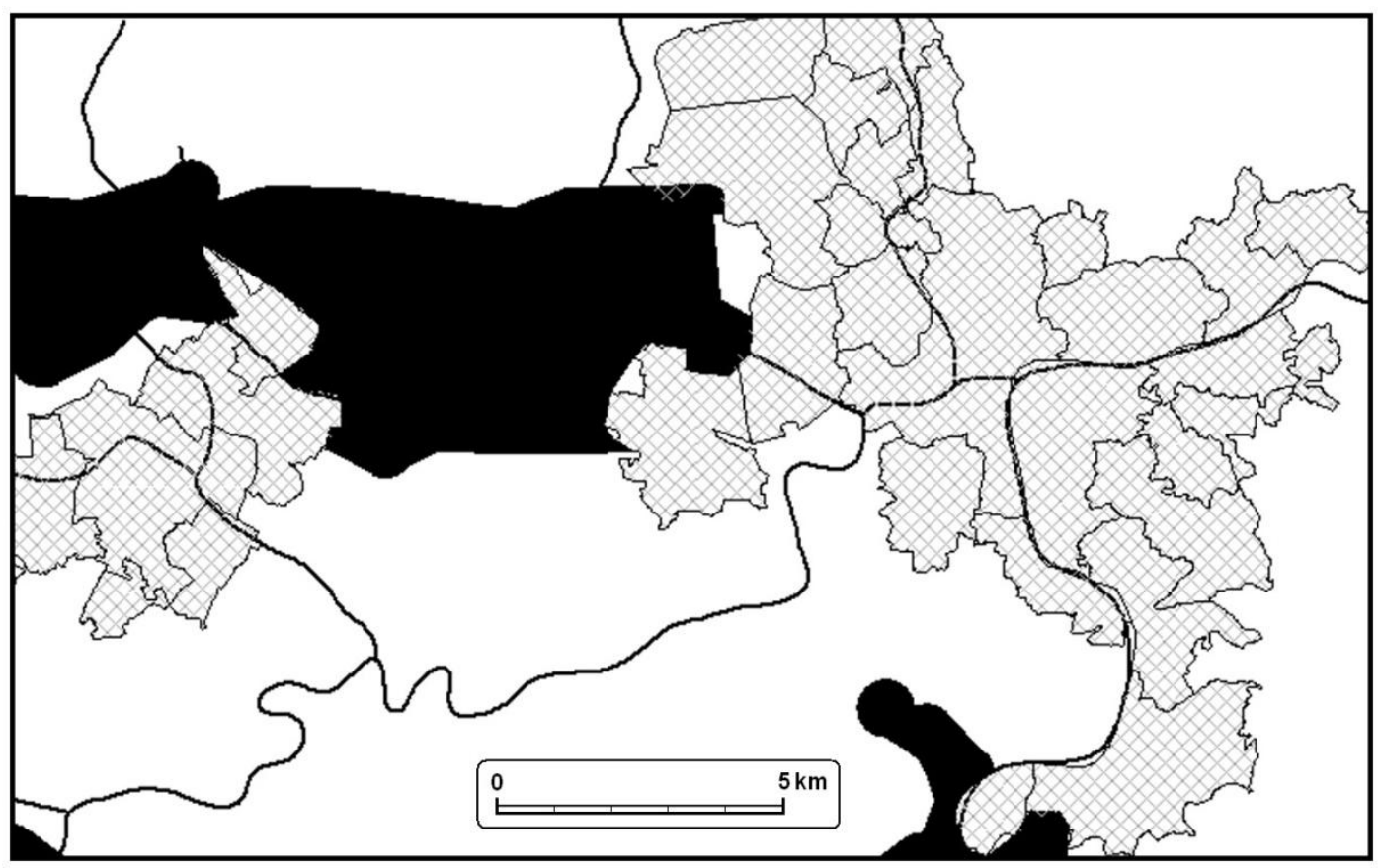

Fig. 5. Example of rounding contours of identified areas of post-industrial landscapes larger than $5 \mathrm{~km}^{2}$ (Data sources: CENIA, Czech Geological Survey, CORINE LC 2006, CzechInvest, ČÚZaK, ČSÚ)

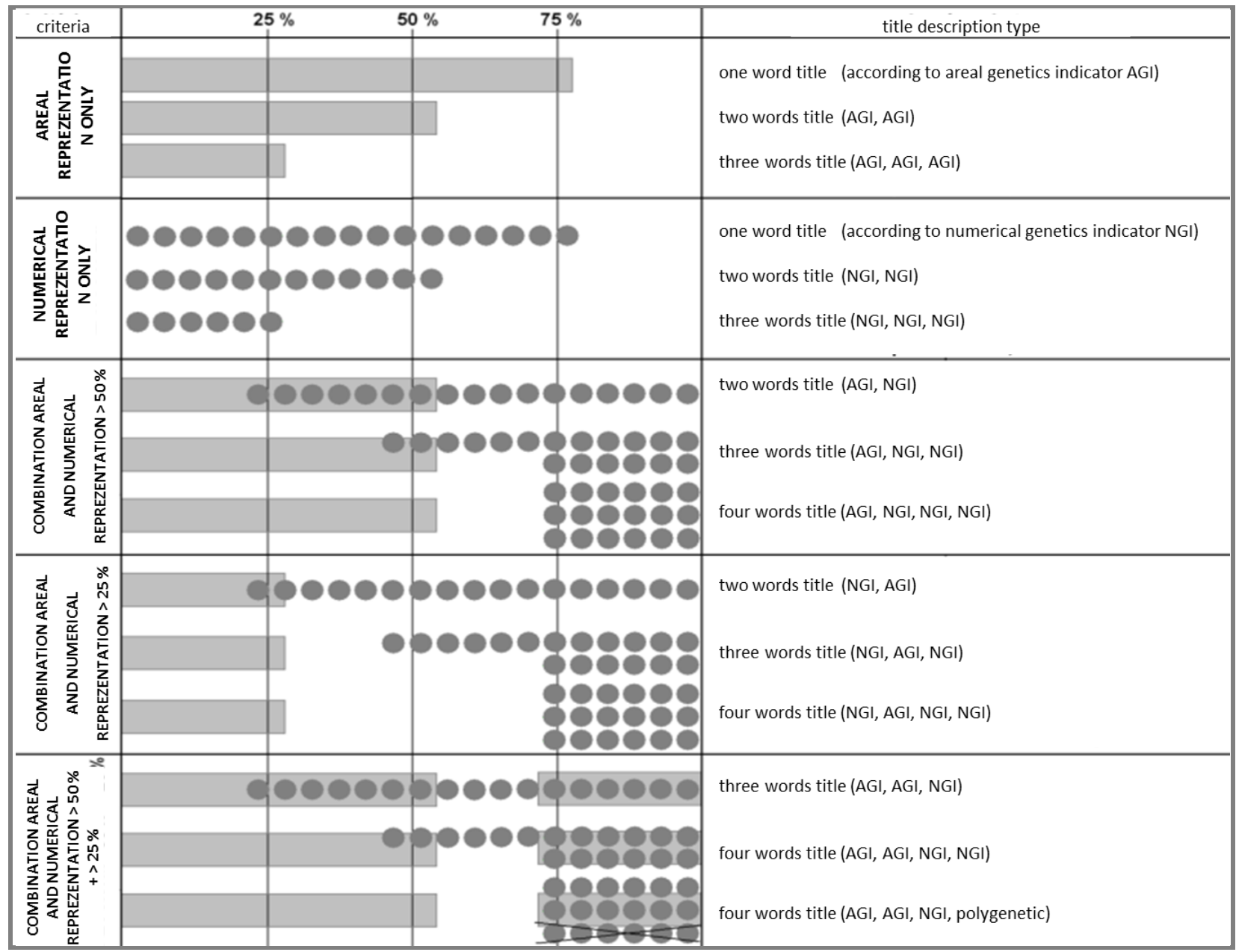

Fig. 6. The classification scheme of defined post-industrial landscapes into genetic types identified by one-to-four words titles 


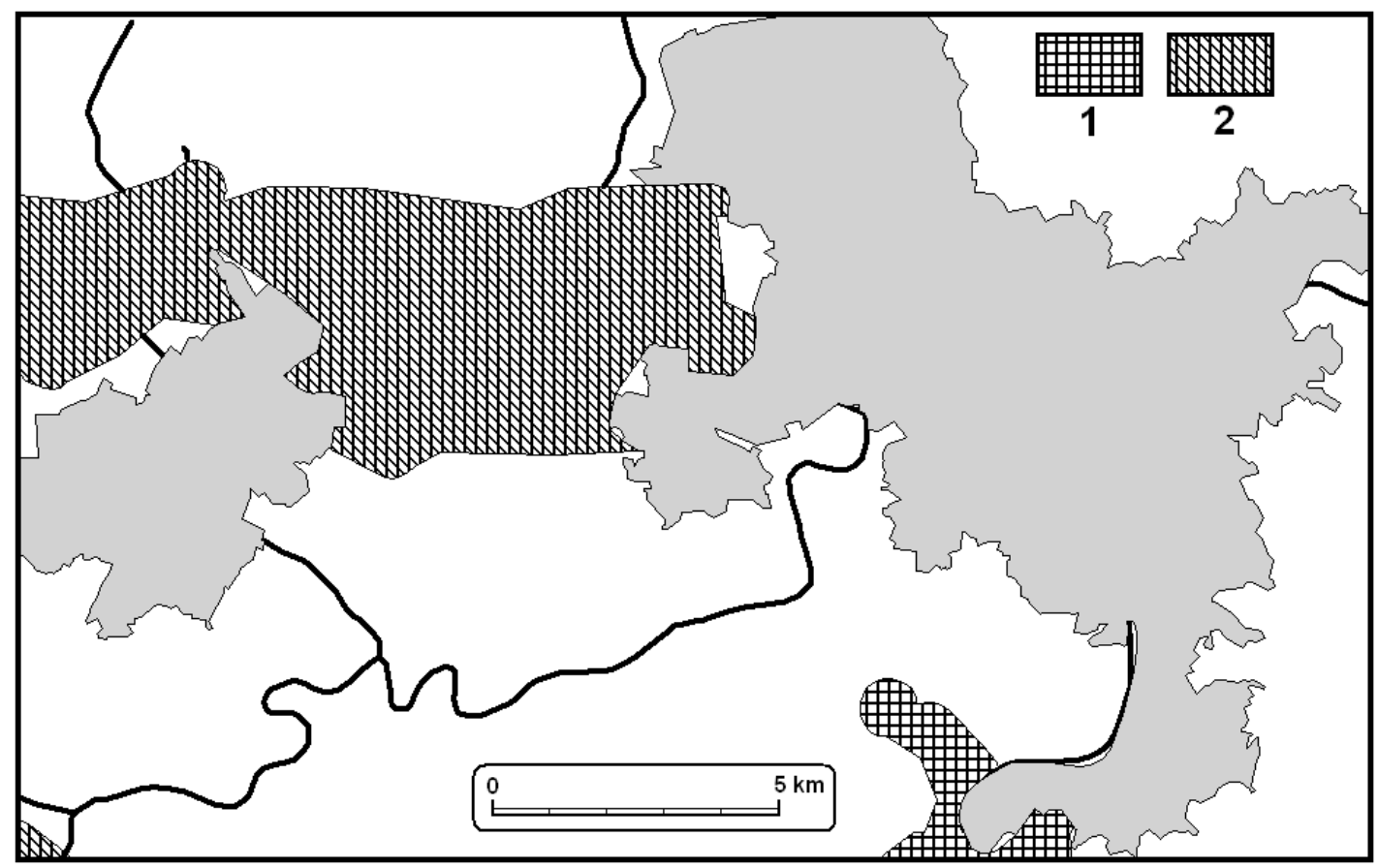

Fig. 7. Types of defined post-industrial landscapes 1 - mining-machinery; 2 - mining

Step 10: Determination of numerical characteristics of defined post-industrial landscapes. Central offices and planning institutions for their decisions need - except for position and classification characteristics - necessarily also the numerical data which allow to estimate for example the range of investments needed, to assess the temporal and transport aspects in accessing territories and so on, and in particular to define problems, criteria for evaluation and formulate approaches to the possible urban and landscape planning solutions. This information, including the location in the Czech Republic, is contained in the catalogue section of this publication.

\section{The post-industrial landscapes of the Upper Silesian corridor}

In the area of interest four large postindustrial landscapes were identified by using the procedure described and with additional support field research in 2013. These landscapes are named after their key residential sites: Studénka region (A), Paskov region (B), Orlová region (C) and Stonava region (D) (Fig. 8).

The post-industrial landscape Studénka region is closely linked with railways and the development of the railway network. The initial impulse for the emergence of PIL was the completion of the railway line - Emperor Ferdinand Northern Railway in 1847, which led to the industrialization of formerly agricultural region, where lime works, sugar factory, distillery were established not long thereafter. The most important one, however, was a factory for the manufacture of railway cars Vagonka (construction started in 1900), which is the core of the specified area. In 1928 it became part of the Ringhoffer Group, after 1945 part of Tatra Kopřivnice. The factory has produced about 90000 of different types of railway cars for passenger and freight transport during its existence. Apartment buildings, social and sports facilities for employees were gradually built in the area around the factory. In 2000, one of the successor organizations - ČKD VAGONKA STUDÉNKA, a.s. was sold and subsequently the production of passenger railway cars was moved to Ostrava - Vítkovice.

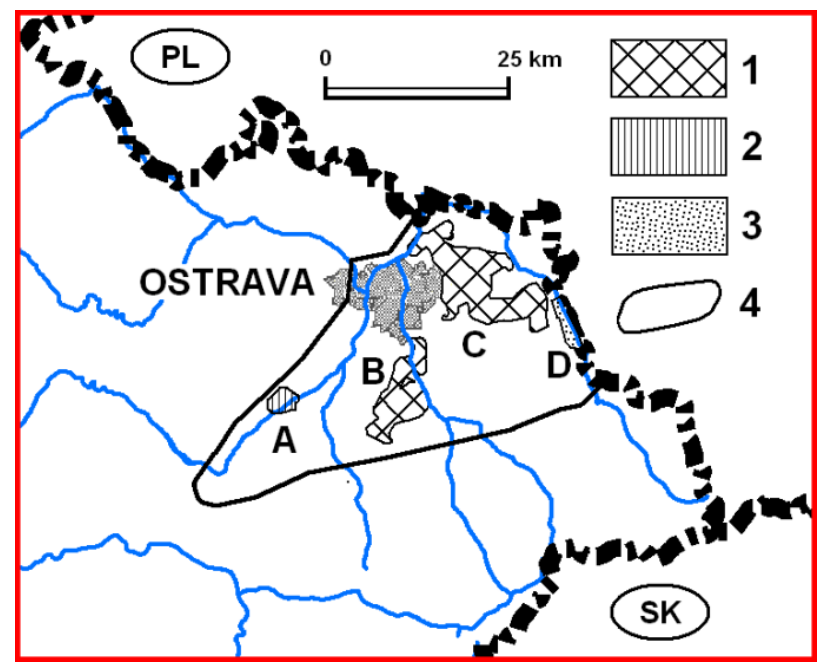

Fig. 8. Types of post-industrial landscapes in the region of Ostrava in Upper Silesian corridor

1- mining; 2 - engineering; 3 - logging and settlement; 4 - boundaries of the area of interest 
Today, the successor company MSV Metal Studénka works on the part of the premises. The second owner of the premises is AK 1324 s.r.o. company, which sells stainless steel and refractory materials. The manufacture of railway cars took place in a large area (about 40 ha), which was too large and its operation was very expensive for the changed economic situation after 1989. Currently, the premises are divided, most areas and buildings are abandoned and offered for rent. Also, the technical condition of some railway station buildings (railway car workshop, warehouse, depot) that are unused for a long time is very poor, and their further use is still being sought. The western edge of the post-industrial landscape is made up of the area of agricultural primary production with a silo of ZZN Nový Jičín and manufactory of building materials production, company Cemix. Railway transport has left a significant mark in post-industrial landscape since Studénka acts as a regional railway junction and it corresponds to its background, such as that the most of the buildings on the local station (the original station of Studensko-štramberské track) dates back to the $19^{\text {th }}$ century, and now they present rarely seen preserved complex of buildings autonomous railway. The post-industrial landscape Paskov region is connected with a coal mining in the Ostrava agglomeration region. In the history, the area acted as an agricultural hinterland of developing industrial centres on the territory of today's Ostrava and Frýdek-Místek. It was not until the construction of railroads Ostrava-Frýdlant nad Ostravicí in the years 1869-1870 which brought the impulse for industrial development. The last owners of the estate Paskov before the land reform were Stolbergs. At that time, a distillery, a soft drinks company and a pulp production were in the Paskov cadastre. The origins of mining are much younger there and just go back to the beginning of the $60 \mathrm{~s}$ of the $20^{\text {th }}$ century. These were the first mines of Ostravsko-karvinský district which were built in the Beskydy region (DOPITA ET AL., 1997). Interest in coal mining here dates back to the early $20^{\text {th }}$ century, when the experimental deep drilling was carried out. At the end of 1954 the exploratory works started and then 5 years later a mine was begun to build and in 1966 the mine Paskov was already mined for coal (at the nearby Staříc mine from 1969). The highest level of the mining was achieved in Paskov in 1989 (835,000 tons of coal), in a larger mine Staříc it was 1.45 million tons of coal in 1988. After liquidation of the mine Paskov in 1999, the Staříc mine is currently the only active mine in the Ostrava part of the mining district with 963,000 tons of coal per year (data from 2010) and employment of about 2900 people. In 2013, the closure of this mine was announced as well. In hydrological terms, the interesting fact is that about $28-43000 \mathrm{~m}^{3}$ of mine water that is let out into Ostravice each month (data from 2000 - ČERNÝ ET AL., 2003). In the area of this post-industrial landscape there are 6 heaps, which constitute the dominant features of the landscape (Fig. 9). Other significant changes of the landscape took place in recent decades also in the social structure of monitored municipalities (industrialization since the $60 \mathrm{~s}$ of the $20^{\text {th }}$ century, as well as residential suburbanization especially in recent years). Apart from the mines, also the production of pulp was developed (the Biocel Paskov company built in the late 70 s and 80 s of the $20^{\text {th }}$ century, now owned by German group Lenzing, produces about 280,000 tons of pulp per year), food industry (soft drinks production), agricultural production in greenhouses (production of vegetables and flowers - today it is demolished and grassed), pre-cast concrete plant Prefa (today only scrap processing). An important business entity in Paskov is also the largest sawmill in the Czech Republic - Mayr-Melnhof Holz Paskov, whose area is next to the Biocel and which processes about 1 million $\mathrm{m}^{3}$ of wood. In the background of this wood processing operation (production of wood chips for Biocel, as well as sawdust and wood shavings) the follow-up furniture production is developing, as well as pallet factory, pallets and briquettes production and manufacture of roof structures. The most striking problem of postindustrial landscapes of the Paskov region are both contaminated areas on the above mentioned heaps, and reusing many abandoned buildings of industrial plants (brown fields), respectively their lack of use.

Composition of the post-industrial landscape of the Orlová region is connected with underground black coal mining and its consequences in natural (undermining, decrease of areas, change of the drainage conditions in the area, contamination) and social environment (a specific type of city Orlová). The first prospecting attempts at mapping coal deposits in this area were registered in 1776. During the $19^{\text {th }}$ century, the dynamic industrialization followed. However, by 30 s of $19^{\text {th }}$ century local mining activity was rather a system of surface pits with simple coal mining. First coking plant of whole district was built in1843. During boring the pit Jiří in 1841 mine gas exploded and the pit was backfilled, however, mine gases still leaked away. After the ignition these gases have become a part of a face of the city for the next 100 years as "Orlovský eternal fire" 
and lit the part of the Main Street until 1942. By the end of the 1870s other 10 mining pits were in operation. During boring surveys between Darkov and Stonava in the second half of the $19^{\text {th }}$ century springs of salt water with a high content of iodine were discovered, which are still used for spa treatments at the Darkov spa.

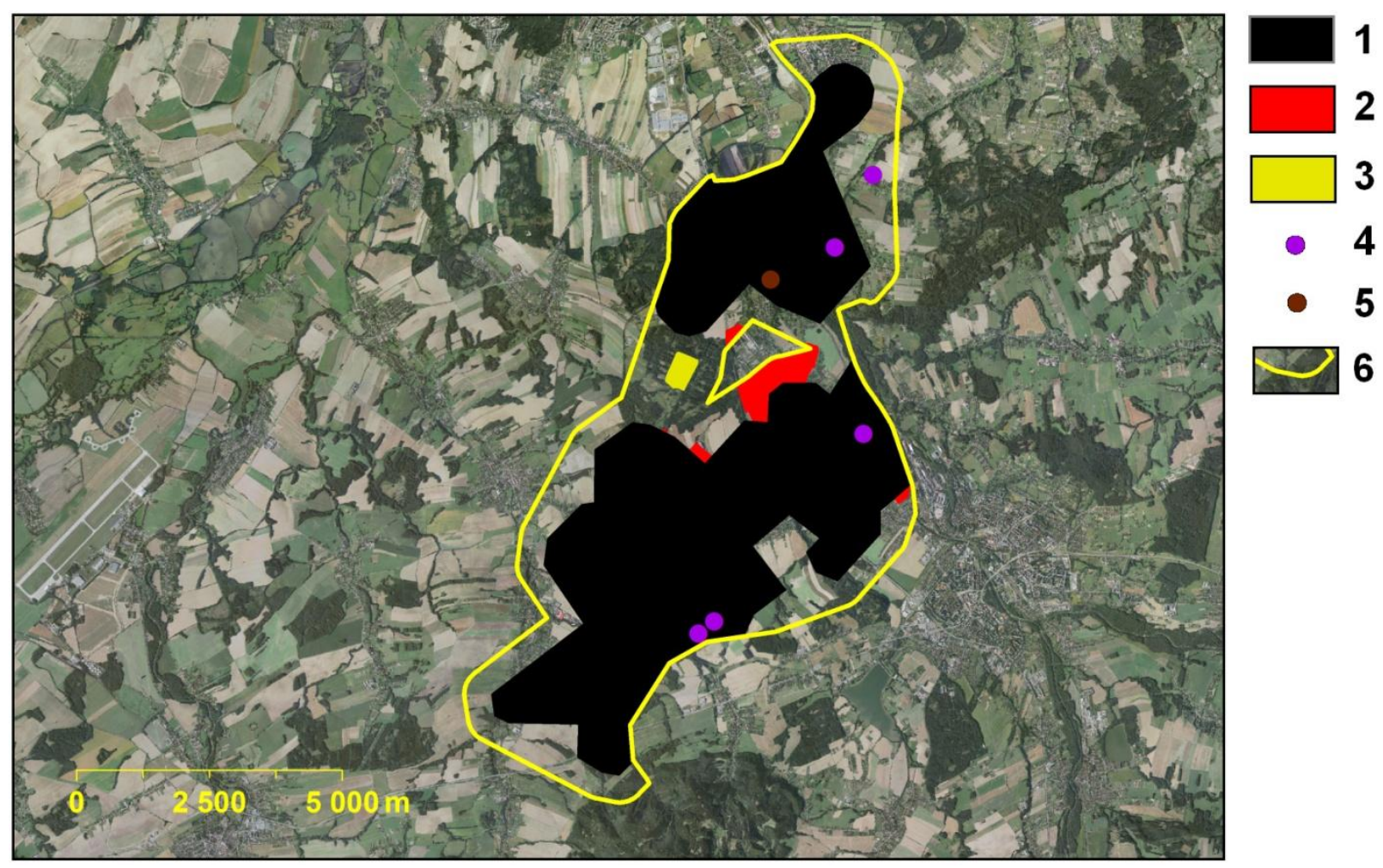

Fig. 9. Example of cartographic documentation of the identified post-industrial landscapes on the example of the Paskov region 1 - mining and undermined areas; 2 - industrial sites with brown fields; 3 - disposal sites; 4 - contaminated sites; 5 - brown fields; 6 - boundary of post-industrial landscape generated by GIS

(The base: colour orthophoto from the CENIA database. Data sources: CENIA, Czech Geological Survey, CORINE LC 2006, CzechInvest, ČÚZaK, ČSÚ)

After closing the mines at the beginning of 1990s, a significant part of mining in the area was concentrated in the mine Darkov. Mining continues here. From the perspective of the post-industrial landscape elements especially space of the original location of Karviná on the territory of today's urban area called Doly deserves a particular comment (Karviná was demolished with the proceeding mining in 1950s, and a name Karviná was transferred to the neighbouring Fryštát and the population placed to housing estates). The original urban built-up area of Karviná, part of Darkov and Doubrava. The post-industrial landscape is complemented by heaps and sludge lagoons, which are largely contaminated. Those which are located in the south are partly used as an industrial zone, partly they deteriorate. Among the elements of the post-industrial landscape can be also included the mining colonies built in the backgrounds of developing mines (Horní Suchá, Karviná-Doly, Orlová, Petřvald etc.), now inhabited mainly by underprivileged population. Current issues are connected especially with pollution from waste heaps and with undermining. The post-industrial landscape of the Stonava region is an area heavily affected by the coal mining from nearby mines. The existence of local elements of the postindustrial landscape is also closely related to the mining. Farmstead was known for breeding foals and cheese making in the $19^{\text {th }}$ century. The nearby castle with the court was nationalized after the Second World War and a local agricultural cooperative was housed there until it was devastated by the undermining and in the mid1960s it was demolished (today this unmarked area is overgrown by self-seeding shrubs). Only the $20^{\text {th }}$ century was the last century devastated by mining activities. In 1960, mines ČSM North, ČSM South, Darkov were established in the municipality and prepared a plan was prepared to build the largest coking plant in the country, but this plan was abandoned. However, the devastation of the mines surroundings continued in order to displace the local parts Amerika and the territory 
on the borders with the municipality Horní Suchá till the mid 1960s. The population was still slightly declining. Approximately a quarter of the population is the population of Polish nationality. On the territory of the post-industrial landscape of the Stonava region the black coal is still mined, in the eastern and western parts of the land there are located sludge lagoons. The most serious current problem of the post-industrial landscapes of the Stonava region are the undermining caused by mining activities, causing devastating declines of buildings and changes in the drainage conditions in the area. In the surroundings there are elevated levels of emissions from industry and households.

The post-industrial landscapes of the area of interest mentioned above are characterized by a retreat from the original industrial and other similar activities and an activation of "newer" industries, often in cooperation with foreign investors. The objects and areas from the time of the industrial society outweigh the buildings and areas of current activities in the country. It is a matter of time when the post-industrial landscapes "disappear", i.e. when the products of contemporary activities outweigh the industrial heritage in the landscape character. It would be a reasonable compromise if the appropriate heritage elements were adapted for the contemporary life in various ways (from the protection to the conversion), and thus viable elements of the past passed as a memory to future generations.

\section{Discussion and conclusions}

The strength of the demonstrated solution of issues of identification and typology of postindustrial landscape is its foundation on generally available data. Another advantage is that the process is based on the use of GIS technology. This ensures that at any given location the data will be processed in the same manner and the quality of results will be homogeneous throughout the treated area. An important strength of this approach is its simplicity and transparency which in essence prevent from different interpretations of the results. The weakness of this solution is mainly using of single packaging buffer with the width of $500 \mathrm{~m}$. In this case, it is possible to discuss about that width, about the constancy of the width and about the shape of the resulting areas. The width $500 \mathrm{~m}$ of the buffer is the result of the experiment and it is undoubtedly a compromise outcome of the discussion, which included both aesthetic and synergistic effects of the various objects of industrial heritage on the area.
Also a selection of criteria used to define the postindustrial landscape can be considered as a weakness. The selection is conditional by the available data sets. They cover only part of the post-industrial landscape characteristics. Due to the current territorial concentration of the symptoms of the post-industrial landscape (their synergy and synchorie) can be assumed that where there are significant concentrations of the symptoms, there will be also the concentration of most of the other characters, although the reliable data on them are not available. In unusual cases of the postindustrial landscapes, however, this assumption may be fatal.

After the phase of identification and classification of the post-industrial landscapes the phase of intense inner study arises. It is necessary to know the internal structure of such landscapes and relationships between objects and areas. Specifying topographic data can be based on this knowledge, including the specification of borders (e.g. with regard to property relations, i.e. the shape and distribution of plots in the real estate cadastre) and suggestions for solving problems with regard to optimizing the territorial structure. Since it is not an "urban" post-industrial landscape (meaning metropolitan), the space opens up not only for architects, but also for territorial and landscape planning.

\section{Acknowledgements:}

This paper was compiled on the basis of research results taken during the grant project "The fate of Czech post-industrial landscape" No. IAA 300860903 supported by the Grant Agency of the Academy of Sciences of the Czech Republic and the project "Upper Silesian corridor - brown fields as development challenge." Korytarz Górnośląski - nieużytki postindustrialne jako wyzwanie rozwojowe No. 222333 supported by the Ministry of Foreign Affairs of the Czech Republic in the AB programme.

\section{References}

Antrop M. 2005. Why landscapes of the past are important for the future. Landscape and Urban Planning, 70, 1: 21-34.

Cashen D. 2007. Redeveloping a North Florida PostIndustrial Landscape. Journal of Undergraduate Research, 8, 3:1-12, [cit. 2010-01-18] URL: http://www.clas.ufl.edu/ jur/200701/papers /paper_cashen.html.

Conesa H.M., Schulin R., Nowack B. 2008. Mining landscape: A cultural tourist opportunity or an environmental problem? The study case of the Cartagena-La Unión Mining District (SE Spain). Ecol. Economics, 64: 690-700.

Černý L. et al. 2003. Uhelné hornictví v Ostravsko-karvinském revíru. Anagram, Ostrava.

Dopita, M. et al. 1997. Geologie české části hornoslezské pánve. Ministerstvo životního prostředí ČR, Praha.

Dulias R. 2009. Landscape planning in areas of sand extraction in the Silesian Upland, Poland. Landscape Urban Plan., DOI:10.1016/j.landurbplan.2009.12.006.

Dunham-Jones E. 2007. Economic Sustainability in the PostIndustrial Landscape. [in:] Tanzer K., Longoria R. (eds.) 
The Green Braid. Towards an Architecture of Ecology, Economy, and Equity, An ACSA Reader, Routledge, London: 44-59.

Ferguson C.C. 1999. Assessing Risks from Contaminated Sites: Policy and Practice in 16 European Countries. Land Cont. Reclam., 7, 2: 33-54.

Fragner B. 2005. Postindustriální krajina (Porúří-Emscher Park). Vesmír, 84, 3: 178-180.

Hansen H., Winter L. 2006. The Heterogenous (Post-) Industrial Landscape of Copenhagen: Location Dynamics and Divisions of Labour. [in:] Proc. of the Sixth European Urban \& Regional Stud. Conf., Roskilde: 1-26. [cit. 2010-01-19] URL: http://www.byforskning.dk/publikationer/Siden\%20publi kationer /artikler/ Hogni20Hansen0LarsWinther.pdf.

Hayes B. 2006. Infractructure: A Field Guide to the Industrial Landscape. W. W. Norton \& Co., London.

Hladnik D. 2005. Spatial structure of disturbed landscapes in Slovenia. Ecol. Engin., 24: 17-27.

Hüttl R. F. 1998. Ecology of post strip-mining landscapes in Lusatia, Germany. Environ. Science and Policy, 1: 129-135.

Keil A. 2005. Use and Perception of Post-Industrial Urban Landscapes in the Ruhr. [in:] Kowarik I. \& Körner S. (eds.) Wild Urban Woodlands. Springer, Berlin-Heidelberg: 117-130.

Kirk J. 2003. Mapping the Remains of the Postindustrial Landscape. Space and Culture, 6, 2:178-186.

Kirkwood N. 2001. Manufactured Sites. Rethinking the PostIndustrial Landscape. Taylor and Francis, London.

Klusáček P. et al. 2011. Vztah lokální samosprávy k post industriální krajině na území České republiky. Moravian Geogr. Reports, 19, 4: 18-27.

Kolejka J. 2006. Rosicko-Oslavansko: Krajina ve spirále. Životné prostredie, 40, 4:187-194.

Kolejka J. 2010. Post-industrial landscape - its identification and classification as contemporary challenges faced by geographic research. Geogr. Technica, 5, 2: 67-78.
Kolejka J. et al. 2012. Postindustriální krajina Česka. Soliton, Brno.

Kolejka J., Klimánek M., Fragner B. 2011: Post-industrial Landscape: Case of the Liberec Region. Moravian Geogr. Reports, 19, 4: 3-17.

Kolejka J., Klimánek M. 2012. Vymezeni a typologie postindustriální krajiny Česka. Geografie - Sborník České geografické společnosti, 117, 3: 289-307.

Ling Ch., Handley J., Rodwell J. 2007. Restructuring the Postindustrial Landscape: A Multifunctional Approach. Landscape Res., 32, 3: 285-309.

Loures L. 2008. Industrial Heritage: the past in the future of the city. WSEAS Transactions on Environ. and Development, 4, 8: 687-696.

Rogers S. 2006. Forgotten Landscapes. Forgotten Landscapes Partnership, [cit. 2010-02-06] URL: www.forgotten landscapes.org.uk/FL_ProjectBrief Aug06.doc.

Rulkens W.H., Honders A. 1996. Clean-up of contaminated sites: Experiences in the Netherlands. Water Science and Techn., 34, 7-8: 293-301.

Shahid Y., Nabeshima K. 2005. Japan's Changing Industrial Landscape, World Bank Policy Research Working Paper No. 3758. [cit. 2010-01-15], URL: http://ssrn.com/ abstract $=844847$.

Sklenicka P., Charvatova E. 2003. Stand continuity - /a useful parameter for ecological network in post-mining landscapes. Ecol. Engin., 20: 287-296.

Stuczynski T. et al. 2009. Geographical location and key sensitivity issues of post-industrial regions in Europe. Environ. Monit. Assessment, 151: 77-91, DOI 10.1007/s10661 -008-0251-4.

Vráblíková J., Vtáblík P. 2007. Využívání území v průmyslové krajině. [in:] Střelcová K., Škvarenina J., Blaženec M. (eds.) "Bioclimatology and Natural Hazards", Int. Sci. Conf., Pol'ana nad Detvou: 1-5. 